\title{
PONDOK PESANTREN SALAFIYAH AL-MANSHUROH (FORUM KOMUNIKASIAHLUSUNNAH WAL JAMAAH AMBON) \\ Pondok Pesantren (Boarding School) Salafiyah Al-Manshuroh (Communication Forum Ahlusunnah Waljamaah Ambon)
}

\author{
Oleh: Badruzzaman* \\ * Peneliti Pada Balai Penelitian dan Pengembangan Agama Makassar \\ J1. A.P. Pettarani No.72 Makassar \\ E-mail: bz69badruzzaman@rocketmail.com
}

\begin{abstract}
Abstrak
Penelitian kualitatif ini bertujuan untuk mengetahai penyelengaraan pendidikan Pondok Pesantren Salafiyah yang diselenggarakan oleh Forum Komunikasi Ahlusunna wal Jamaah Ambon. Forum Komunikasi Ahlusunnah wal Jamaah menjadikan $P P$ Salafivah sebagai salah satu komponen pembelajaranyang diselenggarakan bersamaan dengan SD Islam "-radii. Madrasah Ibtidaiyah Terpadu dan Madrasah Diniyah. Sistem penyelenggaraan PPS ini berimplikasi kepada -aelasan komponen-komponenyang menyertai sebuah satuanpendidikan keagamaan seperti tenagapengajar, tenaga administrasi, sarana dan prasarana, alat pembelajaran, bahkan pada sistem pengelolaan satuan pendidikan keagamaan. Komponen-komponenyang disebutkan tampaknya dimiliki bersama oleh semuajenis satuan pendidikan keagamaannyang a.selenggarakan oleh Forum Komunikasi Alhulussuna wal Jamaah. Program pembelajaranyang diterapkan oleh lembaga pendidikan keagamaan tersebut memadukan tiga model kurikulum, yaitu kurikulum madrasah yang digunakan di Saudi Arabiyah. kurikulum Departemen Agama dan kurikulum pesantren. Beberapa program pembelajaran itu adalah tahfizdul Our 'an. dan pembelajaran bahasa Arab dengan menggunakan kitab-kitab berbahasa Arab.

kata Kunci: penyelenggaran, pembelajaran, pesantren salafiyah.
\end{abstract}

\section{Abstract}

This qualitative study aims to determine the implementation of education process in Pondok Pesantren (PP) of Salafiyah organized by Communications Forum of Ahlusunna Wal Jamaat Ambon. Communications Forum of Ahlusunna Wal Jamaah in Ambon became Pondolk Pesantren Salafiyah as one of learning component carried out with integrated Islamic primary School, Integrated Madrasah Ibtidaiyah and Diniyah. This the implementation system this PPS implies to the obscurity ofcomponents that accompanies a unit education system ofreligious education such as teachers, staff administration, facilities and infrastructure, learning tools, even on a system of religious education management unit. The components mentioned apparently shared by all types of religious education unit organized by Forum Communication A hiusunna Wal Jamaah. Learning programs implemented by institutions of religious education curriculum, integrating the three models, namely the Madrasah curriculum used at Arab Saudi, curriculum of Ministry of Religious Affairs and the Pondok Pesantren curriculum. Some learning programs are tahfizdid Qur 'an and learning Arabic using the Arabiclanguage books.

The coaching of PP Salafiyah should be intensified, focusing on empowerment so that they can become a unit of specific 'eiigious education and independent based on Government Regulation No. 55 of 2008 concerning religion lesson and Religious Education. Beside, required a study to teach book learning in religious education institutions according to the $\bullet 1$ education. Efforts to design a learning books in Arabic that later used as the learning standard at units of religious education both formal and non formal.

kel Words: organizing, learning, salafiyah pesantren

\section{F N D A H ULU A N}

$\mathrm{E}$ ksistensi PP Salafiyah dalam sistem pendidikan Indonesia telah kuat. Undang-Undang Sisdiknas RI No 20 Tahun 2003 menjelaskan * jndidikan keagamaan, karena secara eksplisit bagian integral dari sistem pendidikan nasional.' Bahkan dalam PP Nomor 55 Tahun 2007 disebutkan bahwa pendidikan keagamaan Islam terdiri atas pendidikan diniyah dan pondok pesantren.

Penguatan eksistensi pondok pesantren dalam sistem pendidikan nasional, baik secara filosofis maupun secara historis dan yuridis, memberikan indikasi

Media Pustaka. 2008. "Undang-Undang Republik Indonesia Nomor 20 Tahun 2003 tentang Sistem Pendidikan Nasionaldan .nig Republik Indonesia Xomor 14 Tahun 2005 tentang Guru dan Dosen" Jakarta: Transmedia Pustaka. hi 5.

Direktorat Perguruan Tinggi Kementerian Pendidikan Nasional. 2007. Veraturan Pemerintah Republik Indonesia Nomor 55 Tahun cnlang Pendidikan Agama Dan Pendidikan Keagamaan (http://vlvw.dikti.go.id/tatalaksana/upload/pp_55_2007 pdf).

ii "Al-Qalam" Volume 17 Nomor 1 Januari - Juni 2011

tsi naskah I tangal 14 Maret 2011. Koreksi naskah 11 tanggal 10 April 2011. Finalisasi Naskah 19 Juni 2011 
bahwa tanggung jawab PP Salafiyah menyelenggarakan wajib belajar pendidikan dasar (wajar diknas) 9 tahun disamping pembelajaran kitab-kitab klasik. ${ }^{3}$ Tanggung jawab dituangkan dalam kesepakatan bersama antara Menteri Pendidikan Nasional dan Menteri Agamamelalui Surat Keputusan Bersama Nomor: 1/U/KB/2000 dan Nomor: MA/86/2000 tentang PP Salafiyah sebagai pola wajib belajar pendidikan dasar sembilan tahun. Kesepakatan tersebut ditindaklanjuti dengan keputusan bersama Direktur Jenderal Pembinaan Kelembagaan Agama Islam Departemen Agama dengan Direktur Jenderal Pendidikan Dasar dan Menengah Departemen Pendidikan Nasional Nomor: E/83/2000 dan Nomor: 166/ C/kep/DS/2000 tentang Pedoman Pelaksanaan Pondok Pesantren Salafiyah sebagai Pola Wajib Belajar Pendidikan Dasar. ${ }^{4}$

Sejak ditetapkannya pondok pesantren salafiyah sebagai penyelenggara program Wajib Belajar Pendidikan Dasar pada tahun 2000/2001 sampai tahun 2006. santri yang belum terserap dalam satuan pendidikan wajib belajar pendidikan dasar formal itu sebagian telah terjaring dalam program wajib belajar pendidikan dasar pada pondok pesantren salafiyah. Data tahun 2007 ada sekitar 588.098 santri peserta Program Wajib Belajar 9 tahun, 221.827 tingkat Ula' (setara SD/ MI) dan 366.261 tingkat Wustha (setara SMP/MTs).

Perhatian dan pandangan terhadap eksistensi pondok pesantren salafiyah, penyelenggaraannya terkesan belum optimal. Beberapa aspek yang terkait di dalamnya, antara lain perhatian pemerintah dan masyarakat serta sistem pengelolaan PP Salafiyah. Aspek pertama, bahwa perhatian terhadap PP Salafiyah yang belum memadai baik dari sisi penganggaran, pengakomodasian terhadap lulusan, penyediaan ketenagaan, pembinaan dan pengembangan walaupun telah ditetapkan sebagai salah satu penyelenggaraan wajar diknas 9 tahun. Hal serupa dengan perhatian masyarakat (aspek kedua), perhatian masyarakat yang mulai redup, baik dalam bantuan pendanaan, maupun animo dalam memasukkan anaknya belajar di PPSalafiyah, dibanding dengan madrasah dan sekolah umum. Aspek menajerial pun demikian (aspek ketiga), pengelolaan oleh pengelola PP Salafiyah umumnya masih dikelola secara apa adanya. Di antaranya penyediaan sarana dan prasarana, kurikulum, ketenagaan, sumber-sumber belajar, proses belajar mengajar, manajemen pengelolaan dan aspek-aspek lainnya walaupun dengan segala keterbatasannya, PP Salafiyah masih tetap eksis di masyarakat.

Penyelenggaraan PP Salafiyah menarik untuk diamati. Salah satu diantaranya penelitian yang dilakukan oleh M. Murtadho yang dilakukan di enam propinsi dengan judul penelitian "Penuntasan Wajar Diknas dan Ketersediaan Bahan Ajar di Pesantren Salafiah". Penelitian tersebut menyimpulkan bahwa program wajar diknas di Pesantren Salafiyah cukup diminati masyarakat di daerah penelitian, terlihatjumlah santri yang tertampung pada Pondok Pesantren Salafiyah yang diteliti. Hanya saja ketersediaan sarana dan prasarana pembelajaran yang belum memadai. Salah satunya adalah ketersediaan bahan ajar ratarata hanya $32,75 \%$. Bahkan buku tatap muka untuk wajar dikdas (IPS, PPKn, Ekonomi, Sejarah, Geografi, Fisika, Biologi, Bahasa Inggris) hanya $10,25 \% .^{6}$

Berdasarkan fenomena tersebut, maka Balai Litbang Agama Makassar terdorong untuk melakukan penelitian sejenis di Kawasan Timur Indonesia untuk melihat potret pengelolaan PP Salafiyah secara komprehensif. Hal itu penting dilakukan karena merupakan salah satu prioritas yang diamanatkan dalam Renstra Departemen Agama Tahun 2010-2014 dalam penyelenggaraan pembangunan bidang agama, yakni "peningkatan kualitas pendidikan agama dan keagamaan", pengejewantahannya meliputi: (a) menyelenggarakan pendidikan agama yang bermutu bagi semua peserta didik pada semua jenis, satuan, dan jenjang. (b) menyelenggarakan pendidikan yang dapat mencetak ahli agama yang menguasai ajaran agama secara komprehensif, mendalam dan profesional. (c) menyediakan kesempatan pendidikan yang bermutu bagi masyarakat dalam rangka mencerdaskan kehidupan bangsa dan daya saing nasional.

Fuaduddin T.M. 2005. Evatuasi penyelenggaraan wajib belajar pendidikan dasar di Pondok Pesantren Salafiyah, Jakarta: Departemen Agama Rl. Badan Litbang Agama dan Diklat Keagamaan, Puslitbang Pendidikan Agama dan Keagamaan.

Direktoral Jenderal Pendidikan Islam. Direktorat Pendidikan Diniya dan Pondok Pesantren. 2009. Pedoman Penyelenggar i Pondok Pesantren Salafiyah. Jakarta: Direktorat Pendidikan Diniyah dan Pondok Pesantren, Direktorat Jenderal Pendidikan Islam. Departemen Agama.

http://indonesia.pesantrenglonal.org/index.php'.'option=com-content\&task=view\&id =20\&Itemid=53. Dounlowd. 02 Desember 2009.

M. Murtadho. 2007. Penuntasan Wajar Dikdas dan Ketersediaan Bahan Belajar di Pesantren Salafiyah, dalam Edukasi Jurnal Penelitian Pendidikan Agama dan Keagamaan. Jakarta: Puslitbang Pendidikan Agama dan Keagamaan Badan Litbang dan Diklat DEPAG R1.Volume 5 Nomor 1 Januari-Maret 2007. h. 115.

Kementerian Agama Rl. 2009. Renstra Kementerian Agama Rl Tahun 2010-2014. h.4. 
Salafiyah adalah salah satu jalur perluasan jndidikan nasional yang diperankan oleh :erianAgama, terutama programwajarDikdas untuk itu perlu dilakukan penelitian.

\section{PE M B A H A S A N}

\section{PrefiJ Pesantren Salafiyah AI Manshuroh}

Pendirian Pondok Pesantren Salafiyah (PPS) Al $\therefore d T \quad \mathrm{~h}$ merupakan inisiatif Forum Komunikasi JMussunnah wal Jamaah, salah satu bidang pada Laskar Jihad. Komunitas Laskar Jihad

- an kelompok relawanyangmayoritas berasal Inibon yang ketika kerusuhan antara dua - tas penganut agama tahun 1999-2002 yang - - - embantu perjuangan umatIslam. Satu bagian

- :-asi Laskar Jihad yaitu Devisi Pendidikan - $\mathrm{t}$ «bentuk sebuah Forum Komunikasi, yaitu Forum v " <asi Ahlusunnah wal Jamaah. Forum inilah lonudian yang mendirikan sebuah lembaga pendidikan, ?airu Sekolah Dasar Islam Terpadu (SDIT) Al Ifanshuroh pada Juli 2001. Perkembangan selanjutnya SDIT Al Manshuroh, mengembangkan pola pendidikan - - aan dengan berubah nama menjadi Madrasah Um Terpadu Al Manshuroh (MIP Al Manshuroh).

Proses pembelajaran yang diterapkan ber$-"$ an visi' dan misi."Sistem pembelajaranyang -.:-•.!". di lembaga pendidikan in i adalah Full Day

- - iiu - Kurikulumpendidikanumumdiadopsidari urn Nasional yang dikeluarkan oleh Kemen- crim Diknas. sedangkan kurikulum pendidikan agama rsi dari pendidikan agama yang diterapkan di -:\;-.:!'. Ibtidaiyah Kerajaan Saudi Arabia. Selain embaga pendidikan ini juga menekankan

_ : kannya pada penguasaan Bahasa Arab dan

$$
\text { - Alquran. }
$$

PPS Al Manshorah dipimpin A.M Solihin yang maniliki tenaga pengajar sebanyak 35 orang, terdiri

1 laki-laki dan 15 perempuan. Tenaga pengajar

" * berasal dari berbagai daerah. namun mayoritas fcerasal dari Kota Ambon dan sekitarnya. Kemudian disusul dari Jawa Timur yakni $23 \%$ dari seluruh guru/ ustazd. Terdapat pula ustadz yang berasal dari Sulawesi Selatan, Sulawesi Tenggara, dan Gorontalo.

\section{Tabel 1}

Tenaga Pengajar PPS AL Manshuroh Berdasarkan Jenis Kelamin dan Asal Daerah

\begin{tabular}{|l|c|c|c|c|c|c|}
\hline & Ambon & jatim & Sulsel & Sultra & Gorontalo & Total \\
\hline Laki-Laki & 9 & 7 & 3 & 1 & 0 & 20 \\
\hline Perempuan & 12 & 1 & 0 & 0 & 2 & 15 \\
\hline Jumlah & 21 & 8 & 3 & 1 & 2 & 35 \\
\hline
\end{tabular}

Diamati berdasarkan latar belakang pendidikan, tenaga pengajar PPS Al Manshuroh pun beragam. Mayoritas tenaga pangajar PPS Al Manshuroh berlatar belakang pendidikan pesantren, yaitu $51 \%$ dari seluruh guru/ws/az, namun tingkatan pendidikannya hanya setaraf dengan SMU. Selainnya terdapat $11 \%$ guru yang berlatar belakang pendidikan SMU. Terdapat pula guru yang berlatar belakang pendidikan SI, sejumlah $35 \%$ guru, dan mayoritas guru tersebut berlatar belakang pendidikan umum.

Sejumlah $51 \%$ guru yang mengajarkan mata pelajaran umum dan $49 \%$ yang mengajarkan mata pelajaran agama. Guru yang berlatar belakang pendidikan pesantren mayoritas mengajarkan mata pelajaran agama, namun adajuga beberapa guru yang mengajarkan mata pelajaran umum. Hal serupa bagi guru yang berlatar belakang pendidikan umum, Guru PPS Al Manshuroh yang berlatar belakang pendidikan umum juga dipecayakan untuk mengajar mata pelajaran agama.

Tabel 2

Latarbelakang Pendidikan Guru dan Jenis Mata Pelajaran yang Diajarkan

\begin{tabular}{|l|c|c|c|}
\hline \multirow{2}{*}{ Pendidikan } & Mata Pela & aran Yang Diajarkan \\
\cline { 2 - 4 } & Agama & Guru Umum & Jumlah \\
\hline Sarjana Agama & 2 & 1 & 3 \\
\hline Sarjana Umum & 0 & 9 & 9 \\
\hline MA/Pesantren & 14 & 4 & 18 \\
\hline SMU Umum & 0 & 4 & 4 \\
\hline SMTVPesantren & 1 & 0 & 1 \\
\hline Jumlah & 17 & 18 & 35 \\
\hline
\end{tabular}

ini kondisi Maluku sudah pulih, kedamaian sudah tercipta seperti sebelum kerusuhan, karenanya Organisasi Lakar Jihad pun »ch anggota-anggotanya pada tahun 2002. sebagian besar sudah kembali daerah asalnya masing-masing.

rat Keputusan Kepala Kantor Departemen Agama Kota Ambon pada tanggal 22 Juli 2006 Nomor: Kd.25.03/1/PP.0O. 1/246/2006. PPS Al Manshuroh adalah menghasilkan lulusan pendidikan tingkat dasar yang bertaqwa, cerdas lahir maupun batin, berakhlak, terampil, ang berorientasi keislaman dan memiliki wawasan terhadap lingkungan, yang siap untuk melanjutkan ke tingkat pendidikan berikutnya. PPS Al Manshuroh adalah menghasilkan lulusan pendidikan tingkat dasar yang berkualitas dalam menguasai materi dasar pendidikan apr-a memiliki pemahaman yang benar terhadap kitabullah dan Sunnah Nabi saw yang dilakukan melalui pengajaran. dan bimbingan intensif mdasi ilmu keagamaan secara utuh yang berpedoman secara kual kepada AI Qur'an dan Hadist berdasarkan pemahaman salafus sliohh

II day yang dimaksud adalah pembelajaran dilakukan mulai dari jam 8.00 sampai jam 17.00, diciptakan sedemikian rupa agar para

...sra penuh dapat memperoleh ilmu agama yang memadai dan bimbingan untuk praktek (beramal) serta memiliki adab-adab (etika) $\cdot . . '-a$ baik terhadap Allah JallaJalaluhu maupun terhadap sesama manusia. Sedangkan terpadu dimaksudkan adalah menggabung antara
Tc-cidikan umum dan pendidikan agama. 
Jumlah siswa PPS Al Manshuroh saat ini adalah 281 orang, mayoritas berjenis kelamin laki-laki yaitu sejumlah $54 \%$ dari seluruh siswa. Pada tingkatan Ula', ada sejumlah 255 orang santri dan padatingkat wustha ada sejumlah 26 orang santri. Tampak bahwa dari semua tingkatan tampak bahwa santri terbanyak pada tingkatan kelas II Ula', yaitu 75 orang santri, disusul pada tingkatan kelas I Ula' yaitu 62 orang santri. Sedangkan santri yang berjumlah paling sedikit berada pada tingkatan kelas VI Ula', semua santri berjenis kelamin laki-laki. Sedangkan pada tingkatan Wustha jumlah santri sebanyak 26 orang 11 orang pada kelas I dan 15 orang pada kelas II.

\section{Tabel 3}

Jumlah Santri Berdasarkan Jenis Kelamin dan Jenjang Kelas

\begin{tabular}{c|l|c|c|c|c|}
\hline \multicolumn{2}{c|}{ Tinakatan Kelas } & Laki-Laki & Perempuan & Jumlah & Total \\
\hline \multirow{4}{*}{ Ula } & Kelas I & 29 & 33 & 62 & \\
\cline { 2 - 6 } & Kelas 11 & 36 & 39 & 75 & \\
\cline { 2 - 6 } & Kelas HI & 24 & 23 & 47 & \multirow{4}{*}{255} \\
\cline { 2 - 5 } & Kelas IV & 20 & 14 & 34 & \\
\cline { 2 - 5 } & Kelas V & 19 & 11 & 30 & \\
\cline { 2 - 5 } & Kelas VI & 7 & 0 & 7 & \\
\hline \multirow{4}{*}{ Wustlm } & Kelas 1 & 6 & 5 & 11 & \multirow{2}{*}{26} \\
\cline { 2 - 6 } & Kelas II & 10 & 5 & 15 & \\
\hline \multicolumn{2}{|c|}{ Jumlah } & 151 & 130 & \multicolumn{2}{|c}{281} \\
\hline
\end{tabular}

Saat ini PPS Al Manshuroh berdiri di atas tanah seluas kurang lebih $4000 \mathrm{~m}^{2}$ Di atas tanah tersebut dibangun sarana pendidikan, asrama (pondok), rumah ibadah, perumahan para pengajar, lapangan olah raga, dan unit usaha madrasah yang bersifat permanen. Beberapa bangunannya masih dalam kondisi semi permanen, bahkan darurat. Sarana-sarana pendidikan yang telah terbangun yang digunakan untuk proses pembelajaran santri putra di antaranya: kantor semi permanen satu unit, kelas permanen satu unit dan semi permanen lima unit, asrama santri semi permanen tiga unit, mesjid permanen satu unit, asrama guru permanen dua unit dan semi permanen empat unit, untuk perpustakaan dan laboratorium belum ada, dan kamar mandi cuci dan wc permanen empat unit. Sedangkan sarana pendidikan yang dipergunakan oleh santri putri adalah kantor darurat satu unit, kelas permanen 4 unit dan semi permanen dua unit, asrama santri semi permanen limit, perpustakaan dan laboratorium belum ada, dan kamar mandi/wc semi permanen dua unit.

\section{Sistem Pembelajaran PPS Al Manshuroh}

Proses pembelajaran di PPS Al Manshuroh dominan dilakukan secara klasikal, terdiri atas tingkatan Wa'dan WusthaP Klasifikasi santri juga dilakukan berdasarkan jenis kelamin. Santri putra dikelompokkan pada satu sistem pembelajaran yang dominan diajar oleh guru laki-laki, Demikian halnya dengan santri putri, dikelompokkan dalam satu sistem pembelajaran dan dominan diajar oleh guru perempuan. Berdasarkan pemisahan sistem pembelajaran itu, maka semua sarana dan prasarana, alat pembelajaran, proses pembelajaran, sampai kepada penyelenggaraan esktra kurikuler diselenggarkan secara terpisah.

Persentase muatan pelajaran agama $63 \%$ dan umum 37\%.PPS Al Manshuroh menyelenggarakan sistem pembelajaran dengan berupaya untuk menuntaskan tiga kurikulum yang dipadu menjadi satu dengan beban pelajaran berjumlah 660 jam pelajaran. Ketiga kurikulum itu ialah Kurikulum Madrasah Ibtidaiyah Kerajaan Saudi Arabia, ${ }^{14}$ kurikulum Kementrian Diknas PJ, ${ }^{15}$ dan Kurikulum Pesantren. ${ }^{16}$

\section{A. Kurikulum PPS Al Manshuroh}

Dua kurikulum formal, yaitu kurikulum Kementerian Diknas RI dan MI Kerajaan Saudi Arabia diterapkan dengan sistem klasikal sedangkan kurikulum non formal (kurikulum pesantren), diterapkan dengan klasikal dan non klasikal. Penerapan kurikulum Kementerian Diknas RI dilakukan dalam rangka mensukseskan program pemerintah Wajar Dikdas 9 Tahun. Strategi pembelajaran mata pelajaran umum ini dilakukan berdasarkan buku-buku ajar yang telali disusun oleh Kementerian Diknas RI.

\footnotetext{
Didirikan pada tahun 2008.

Kurikulum agama terdiri atas 7 kelompok mata pelajaran, yaitu:

1. Ilmu Alquran, terdiri atas tiga mata pelajaran yaitu: Hifzhul Qur.an, Iqro/Qiroat, dan Tajvvid.

2. Hadits. terdiri atas dua mata pelajaran yaitu Hifdzul Hadits dan Makna Hadits.

3. Bahasa Arab, terdiri atas tiga mata pelajaran yaitu Tata Bahasa, Percakapan dan Khoth/Tahaji

4. Aqidah dan Akhlah

5. Fiqhi. terdiri atas dua mata pelajaran yaitu Matan Fiqhi dan Praktik.

6. Siroh Nabawiyah

7. Doa/Zikir dan Adab.

Kurikulum umum terdiri atas 7 mata pelajaran yaitu: Bahasa Indonesia, Matematika, IPA, IPS, PKN, Keterampilan dan Olah Raga

"Kurikulum Pesantren adalah Tahfizduh Our an dan pembelajaran kitab-kitab berbahasa Arab.
} 
kurikulum Madrasah Ibtidaiyah Kerajaan Saudi Arabia dimodifikasi berdasarkan kemampuan siswaasara. Terlebih dahulu kurikulum dan setiap mata penjaran diterjemahkan ke dalam bahasa Indonesia ieaudian dibuat modul-modul pembelajaran yang asesuaikan dengan kemampuan pemahamaan siswa iipahami secara mudah dan jelas.

Kurikulum non formal terdiri atas pembelajaran liM/Lu/Our'an dan kitab-kitab berbahasa Arab. Pada pembelajaran Tahfizid Qur'an, setiap santri rr»ajibkan untuk mengahafal Alquran. Sistem pnchafalan Alquran pada tingkat Ula 'dimulai darijuz pada tingkat Wustha'dimulai dari juz piiUBM yaitu Al Baqarah (surah 1).

\section{». Takfiz Al Qur'an}

Bagi santri yang masih tingkat pertama atau kelas 1 sanpai kelas 3 Ula 'ditekankan menghafal juz ke 30 --" $-z-. . \quad$ dari Alquran. Penentuan kcdua juz :;:sarkan pada tingkat kemampuan hafalan a a i bahwa bahwa santri kelas I sampai kelas III dmtinan masih berusia antara 6 tahun sampai 9 tahun, kareoanya kemampuanya menghafal Alquran animus pada surah-surah pendek. Di keduajuz

."ir rersebutditemukan palingbanyak surah-surah :<•" - - N Namu m penekanan utama santri-santri kelas

"-• um pada hafalan Alquran. namun pada fcennampuan membaca Alquran secara baik dan benar. Kaaeaahu. proses pembelajarannya dilakukan dengan atsaem klasikal dengan cara talqin.

Ha! serupa berkaitan dengan tahapan jumlah sarah yang dihafal. Setiap jenjang pada tingkatan : '.'-•"_target-target jumlah surah atau juz yang dihafal, bahkan sampai pada tiap semester. - '. >ampai kelas III, santri diharus menghafal ; - surah dalam juz ke 30 dan setelah tamat saekatan Ula'. santri harus menghafal minimal 4 juz, jai ajuz ke 30, 29, 28 dan 27. Pada kelas IV santri maksudnya ialah dilcpas untuk berlomba rerbanyak menghafal ayat-ayat Alquran. Tiagkat hafalan santri terhadap ayat Alquran nantinya ' -- i".2si. ada santri yang menghafap hanya 1 juz. npai 2 juz bahkan ada yang sampai 4 juz.

. ; ... proses pembelajaran kemudian dilakukan

- - pengelompokan berdasarkan jumlah surah $\mathrm{z} \backslash$ ang dihafal oleh santri. Ada santri yang sudah aaduk dikelas V tetapi masih dikelompokkan dengan santri yang kelas IV, demikian halnya dengan ada yang masih kelas IV tetapi sudah ditriompokkan dengan santri kelas V.
Tabel 4

Tahapan Surah/Juz yang Dihafal Oleh Santri

\begin{tabular}{|c|l|l|}
\hline \multicolumn{1}{|c|}{ Tingkatan } & Jenjang/Semester & \multicolumn{1}{|c|}{ Surah/ Juz yang harus Dihafal } \\
\hline \multirow{4}{*}{$\begin{array}{c}\text { U } \\
\text { L } \\
\mathbf{A}^{\prime}\end{array}$} & Semester I Kelas I & Al-Fatihah, Annas sampai AI Zalzalah (Q.S. 99) \\
\cline { 2 - 3 } & Semester II Kelas I & Hafalan sampai surah Ath Thaariq (Q.S. 86) \\
\cline { 2 - 4 } & Kelas III & Seluruh surah dalam Juz ke 30 \\
\cline { 2 - 4 } & Kelas IV - Kelas IV & $\begin{array}{l}\text { Siswa dilepas untuk menghafal sebanyak- } \\
\text { banyaknya, target minimal 4 juz. }\end{array}$ \\
\hline $\begin{array}{c}\text { WU } \\
\text { STHA }\end{array}$ & Kelas I - Kelas III & $\begin{array}{l}\text { Metode hafalan mulai dari juz kedua (AUf, Lam. } \\
\text { Mim/Surah Al Baqarah). Santri di lepas. Minimal } \\
\text { 15 juz yang telah dihafal setelah tamat Wustha. }\end{array}$ \\
\hline
\end{tabular}

Sistem pembelajaran7a/2/?z/z Qur'an dilakukan setiap hari. PPS Al Manshuroh telah menjadwalkan secara akademik sebanyak dua jam pelajaran setiap hari pada semua tingkatan kelas untuk proses pembelajaran Tahfizh Qur 'an. Satu jam untuk proses pembelajaran Muraja 'ah (mengulangi ayat-ayat yang dihafal) dan satu jam pelajaran diperuntukkan untuk proses pembelajaran penambahan hafalan.

Evaluasi pembelajaran Tahfizh Qur'an juga dilakukan seperti evaluasi pembelajaran pada mata pelajaran formal. Evaluasi dilakukan bersamaan waktunya dengan evaluasi mata pelajaran formal tersebut. Setiap tahun ada dua kali dilakukan evaluasi, yaitu setiap semester pembelajaran.

Teknis evaluasi Tahfizhul Qur 'an dilakukan secara face to face. Setiap santri dihadapkan seorang ustadz untuk mengetes hafalannya terhadap Alquran. Jumlah juz yang di-murjaah pada evaluasi tersebut berdasarkan laporan dari guru kelas masing-masing. Secara teknis adalah setiap santri digilir untuk menyetor hafalannya kepada ustadz yang telah ditentukan. Pada penyetoran pertama santri diminta untuk menyetor hafalannya pada satu juz, yaitu juz ke-30, kemudian beralih kepada santri yang lain. Santri pertama tadi dipersilahkan untuk istirahat dan mempersiapkan diri untuk menyetor hafalannyajuz yang lain (juz ke-29).

\section{Pembelajaran Kitab Berbahasa Arab.}

Pembelajaran kitab-kitab berbahasa Arab, dominan diselenggarakan pada tingkat Wustha. Pembelajaran kitab-kitab berbahasa Arab dilakukan dengan sistem klasikal. Kitab-kitab tersebut diajarkan di kelas berdasarkan jenjang pendidikan. Kitab-kitab yang ditekankan untuk dikuasai oleh santri adalah kitabkitab bahasa, sedangkan kitab-kitab lainnya seperti kitab fiqhi, hadis, tafsir dan lain tetap diajarkan namun tidak ditekankan untuk dikuasai oleh santri. 
Beberapa kitab berbahasa Arab yang diajarkan adalah: Taisirul Alain dan Syarah Uhdatul Ahkam (Kitab Fiqhi), Adamul Mufradat (Tata Bahasal Durusul Lughah, Jurumiyah, dan Qathrun Nada (Kitab Bahasa) dan Al Arbain, An Nawawiyah (Kitab Hadist).Khusus pembelajaran kitab-kitab bahasa, dimulai pada kelas tingkatan Ula', yaitu kelas VI Ula' diharuskan menguasai Kitab Durusul Lughah jilid I dan II. Pada tingkat Wustha' kelas I santri harus menguasai Kitab Durusul Lughah jilid III, kelas II mengusai Kitab Al Jurumiyah, dan kelas III menguasai kitab Qatrun Nada'. Pembelajaran kitab-kitab selain kitab bahasa, seperti kitabTaisirul Alam, dilakukan dengan membagi-bagi pada setiapjenjang, bahkan kitab tersebut sudah diringkas sedemikian rupa kemudian diajarkan kepada santri.

Sistem pengajaran kitab-kitab bahasa Arab berbeda dengan sistem pengajaran kitab hadist dan fiqhi. Pada pengajaran kitab bahasa yang ditekankan adalah muhadasah (percakapan), pemahaman nahu, dan khath/imla'. Sedangkan pada kitab-kitab lainnya misalnya hadist, maka penekananya pada hafalan, arti dan makna hadist, dan faidah hadits. Santri diajarkan agar selain menghafal hadist juga faham tentang makna dan faidah hadist sehigga nantinya tidak keliru dalam mengistidlalkan hadits. $^{\wedge^{\prime}}$

\section{PENUTUP}

\section{Kesimpulan}

Forum Komunikasi Ahlusunnah wal Jamaah menjadikan PP Salafiyah sebagai salah satu komponen pembelajaran yang diselenggarakan bersamaan dengan SD Islam Terpadu, Madrasah Ibtidaiyah Terpadu dan Madrasah Diniyah. PP Salafiyah dijadikan sebagai tambahan pembelajaran yang diselenggarakan berdampingan dengan satuan-satuan pendidikan formal lainnya. PPS sebagai sebuah lembaga pendidikan keagamaan yang legal sesuai regulasi pendidikan agama dan pendidikan keagamaan tidak diselenggarakan secara tersendiri dan otonom. Sistem penyelenggaraan PPS ini berimplikasi kepada ketidakjelasan komponen-komponen yang menyertai sebuah satuan pendidikan keagamaan seperti tenaga pengajar, tenaga administrasi, sarana dan prasarana, alat pembelajaran,bahkan pada sistem pengelolaan satuan pendidikan keagamaan. Komponen-komponen yang disebutkan tampaknya dimiliki bersama oleh semua jenis pendidikan keagamaan yang diselenggarakan oleh Forum Komunikasi Alhulussunah wal Jamaah.

2. Program pembelajaran yang diterapkan di lembaga pendidikan keagamaan binaan Forum Komunikasi Ahlusunnah wal Jamaah menerapkan tiga model kurikulum, yaitu kurikulum Madrasah yang digunakan di Saudi Arabiyah, kurikulum Kementerian Agama dan kurikulum pesantren. Beberapa program pembelajaran itu adalah tahfizdulQur 'an, dan pembelajaran bahasa Arab dengan menggunakan kitab-kitab berbahasa Arab.

\section{Rekomendasi}

1. Mengamati PP Salafiyah dijadikan sebagai salah satu program pembelajaran pada satuan pendidikan keagamaan formal, maka pembinaan pengembangan PP Salafiyah perlu ditingkatkan. Pembinaan PP Salafiyah hendaknya diintensifkan dengan berfokus kepada upaya pemberdayaan sehingga mampu menjadi sebuah satuan pendidikan keagamaan yang tersendiri dan mandiri. Legalitas PP Salafiyah sebagai sebuah satuan pendidikan keagamaan telah diregulasi dalam PP Nomor 55 tahun 2008 tentang Pendidikan Agama dan Pendidikan Keagamaan. Olehnyaitu, hendaknya PP Salafiyah dikelola secara manajerial dalam bentuk sebuah satuan pendidikan keagamaan.

2. Upaya pemberdayaan PP Salafiyah sebagai sebuah satuan pendidikan keagamaan tersendiri dan mandiri memerlukan rancangan pola pengembangan, yang nanti dijadikan rujukan oleh setiap komponen, baik pemerintah, masyarakat maupun pengelola PP Salafiyah. Karenanya, kajian pengembangan dalam upaya merancang pola pengembangan pemberdayaan PP Salafiyah urgen untuk dilakukan. Kajian pengembangan tersebut dapat berupa penelitian pengembangan, lokakarya, seminar, atau workshop yang melibatkan pemerintah, masyarakat dan pengelola PP Salafiyah dalam upaya mengkaji lebih lanjut permasalahan menajerial yang dialami oleh PP Salafiyah dan merancang pola pemberdayaan.

Faisol, Pelaksana Tugas Pimpinan PPS Al Manshuroh.Wawancara. 12-10-2010. 
Pembelajaran kitab berbahasa Arab pada satuan-

... pendidikan keagamaan tampak bervariasi. baik dari aspekjenis kitab maupun penjenjangan.

- anva diperlukan sebuah kajian untuk :->:andarisasi pembelajaran kitab dilembaga pendidikan keagamaan berdasarkan jenjang pendidikan. seperti penentuan kitab-kitab tertentu

_ ::ajarkan pada masing-masing jenjang pendidikan (ula wustha' dan ulya'). Kajian -ersebut dapat dilakukan dengan menghadirkan komunitas pesantren dalam upaya merancang desain pembelajaran kitab berbahasa Arab yang -antinva dapat dijadikan sebagai standar - ajaran pada satuan-satuan pendidikan keagamaan baik formal maupun non formal.

\section{-: -inTerimaKasih}

nengucapkan terima kasih kepada semua "-« ; ir.g berperan dalam menyukseskan penelitian -L L capan terima kasih kepada Kepala Balai Litbang Kami Makassar, Kepala Kantor Kementerian Agama Kota Ambon, Pimpinan PP Salafiyah Al Hi ibinth. dan semua informan yang tidak sempat - satu persatu. Semoga kerjasama kita bagi pengembangan dan peningkatan hmfcas pendidikan keagamaan di Indonesia.

\section{- VFTAR PUSTAKA}

\footnotetext{
- -- .- Igama RI 2009. Renslra Dep.Agama RI Tahun 2010-

-.. . Igama. Direktoral Jenderal Pendidikan Islam. 2009 Lhrektorat Pendidikan Diniya dan Pondok Pesantren, Pedoman Penyelenggaraan Pondok Pesantren Salafiyah. - ir.j. Direktorat Pendidikan Diniyah dan Pondok . --:ren. I Mrektorat Jenderal Pendidikan Islam. Departemen A pota

Uttoaooi Peguruan Tinggi Kementerian Pendidikan Nasional. Peratwan Pemerintah Republik Indonesia Nomor 55 Tahun Tentang Pendidikan Agama Dan Pendidikan $\therefore$ an (http: IIIIII.dikii.go.id tatalaksana. upload rr $\quad 55$ 2007.pdf).

_-:: " I M 2005. Evaluasi Penyelenggaraan Wajib Belajar Dasar di Pondok Pesantren Salafiyah. Jakarta : . nen Agama RI, Badan Litbang Agama dan Diklat _. ."..un. Puslitbang Pendidikan Agama dan Keagamaan.
}

M. Murtadho. 2007. Penuntasan Wajar Dikdas dan Ketersediaan Bahan Belajar di Pesantren Salafiyah, dalam Edukasi Jurnal Penelitian Pendidikan Agama dan Keagamaan. Jakarta: Puslitbang Pendidikan Agama dan Keagamaan Badan Litbang dan Diklat DEPAG RL. Volume 5 Nomor 1 Januari-Maret 2007.

Surat Keputusan Kepala Kantor Departemen Agama Kota Ambon pada tanggal 22 Juli 2006 Nomor : Kd.25.03/1/PP.OO. 1/ 246/2006.

Visi Media Pustaka. 2008. "Undang-Undang Republik Indonesia Nomor 20 Tahun 2003 tentang Sistem Pendidikan Nasional dan Undang-Undang Republik Indonesia Nomor 14 Tahun 2005 tentang Guru dan Dosen": Jakarta: Transmedia Pustaka.

http://indonesia.pesantrenglonal.org/index.php?option=comcontent \&task=view \&id=20\&Itemid=53, dounlowd, 02 Desember 2009 .

\section{Wawancara}

Faisol, Pelaksana tugas pimpinan PPS Al Manshuroh. Wawancara 12 0ktober 2010 